\title{
Evaluating hexavalent chromium reduction and electricity production in microbial fuel cells with alkaline cathodes
}

\author{
N. Xafenias $\cdot$ Y. Zhang $\cdot$ C. J. Banks
}

Received: 11 January 2014/Revised: 4 June 2014/ Accepted: 9 July 2014/Published online: 23 July 2014

(C) Islamic Azad University (IAU) 2014

\begin{abstract}
The work investigated the efficiency of microbial fuel cells (MFCs) for the treatment of alkaline hexavalent chromium containing wastewater. When lactate was used as the metal chelator in alkaline $(\mathrm{pH} \mathrm{8)}$ abiotic cathodes, hexavalent chromium concentration dropped from $10 \mathrm{mg} \mathrm{l}^{-1}$ to undetectable levels within the first $45 \mathrm{~h}$ of operation. Power density produced in the $\mathrm{pH} 8$ abiotic cathodes was up to $21.4 \mathrm{~mW} \mathrm{~m}^{-2}$, and in the $\mathrm{pH} 9$ cathodes up to $2.4 \mathrm{~mW} \mathrm{~m}^{-2}$; these values were well comparable with other values found in the literature for biologically catalysed cathodes, even at lower $\mathrm{pH}$ values. When Shewanella oneidensis MR-1 was present in a hexavalent chromium reducing cathode at $\mathrm{pH} 8$, current production contributed by $26 \%$ to the total hexavalent chromium reduced during the 36 days of operation. On the other hand, when hexavalent chromium $\left(10 \mathrm{mg} \mathrm{l}^{-1}\right)$ was controllably added in the anode where S. oneidensis MR-1 was present, up to $73 \%$ of current decreased immediately after every hexavalent chromium addition; this toxic effect remained even after hexavalent chromium was depleted in the anode and strongly indicates that the presence of hexavalent chromium in the anodes of MFCs must be avoided. Overall, our results indicate that alkaline hexavalent chromium wastewater can be effectively remediated in the cathodes of MFCs, provided that a metal chelator is
\end{abstract}

\section{N. Xafenias $(\bowtie)$}

Industrial Biotechnology Group, Department of Chemical and Biological Engineering, Chalmers University of Technology, 41296 Gothenburg, Sweden

e-mail: nxaf@hotmail.com

Y. Zhang - C. J. Banks

Bioenergy and Organic Resources Research Group, Faculty of Engineering and the Environment, University of Southampton, Highfield, Southampton SO17 1BJ, UK present in the cathodes and that hexavalent chromium is not present in the anodes.

Keywords Bioelectrochemical systems - Hexavalent chromium remediation - Shewanella oneidensis MR-1 . Lactate $\cdot$ High $\mathrm{pH} \cdot$ Hexavalent chromium toxicity

\section{Introduction}

Hexavalent chromium (Cr(VI)) has become one of the most abundant inorganic contaminants found in groundwater and has toxic, carcinogenic, and mutagenic effects on the living environment (U.S.E.P.A. 2000). The physicochemical characteristics of $\mathrm{Cr}(\mathrm{VI})$ containing wastewater will very much vary from the strongly acidic chrome plating wastewater ( $\mathrm{Li}$ et al. 2008) to the alkaline chromite ore processing wastewater (Stewart et al. 2007). Various treatment approaches exist but an effective remediation option involves $\mathrm{Cr}(\mathrm{VI})$ reduction to the considerably less toxic trivalent form (Cr(III)) (Brandhuber et al. 2004; Palmer and Puls 1994), according to Eq. 1:

$\mathrm{CrO}_{4}^{2-}+8 \mathrm{H}^{+}+3 \mathrm{e}^{-}=\mathrm{Cr}^{3+}+4 \mathrm{H}_{2} \mathrm{O}$

Even though it is an effective $\mathrm{Cr}(\mathrm{VI})$ remediation method, $\mathrm{Cr}(\mathrm{VI})$ reduction strongly depends on the presence of protons and therefore the $\mathrm{pH}$ of the wastewater. This can also be seen in the Nernst equation, which relates the concentrations of the reactants in the solution with the redox potential of the $\mathrm{Cr}(\mathrm{VI}) / \mathrm{Cr}(\mathrm{III})$ redox couple:

$E^{\prime}=E_{0}^{\prime}-\frac{R T}{n F} \times \ln \frac{\left[\mathrm{Cr}^{3+}\right]}{\left[\mathrm{CrO}_{4}^{2-}\right]\left[\mathrm{H}^{+}\right]^{8}}$

Where $E_{0}^{\prime}$ is the potential at standard conditions $(1.51 \mathrm{~V})$, $R$ is the molar gas constant $\left(8.31447 \mathrm{~J} \mathrm{~mol}^{-1} \mathrm{~K}^{-1}\right), T$ is the 


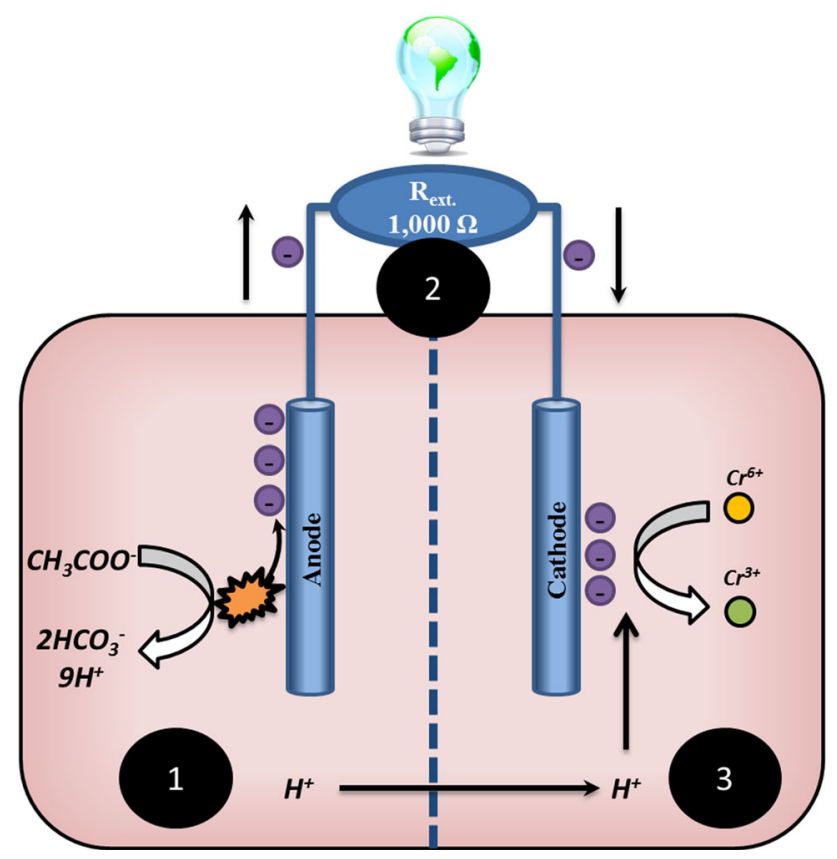

Fig. 1 The concept of $\mathrm{Cr}(\mathrm{VI})$ remediation in MFCs: 1 Anodophilic microorganisms break down organic substrates in the anode, releasing protons and electrons; 2 electrical power is generated when protons and electrons are passing to the cathode through a proton-permeable membrane and an external resistor, respectively; $3 \mathrm{Cr}(\mathrm{VI})$ is reduced to $\mathrm{Cr}(\mathrm{III})$ in the cathode, where depending on the $\mathrm{pH}$, the exact speciation of the produced $\mathrm{Cr}$ (III) will vary

temperature $(\mathrm{K}), n$ is the number of electrons exchanged (3), and $F$ is Faraday's constant $\left(96,485.3 \mathrm{C} \mathrm{mol}^{-1}\right)$. As seen in Eq. 2, the lower the $\left[\mathrm{H}^{+}\right]$concentration (higher $\mathrm{pH})$, the lower the redox potential of the $\mathrm{Cr}(\mathrm{VI}) / \mathrm{Cr}(\mathrm{III})$ couple, and therefore the lower the tendency of $\mathrm{Cr}(\mathrm{VI})$ for reduction.

Microbial fuel cells (MFCs) are a new technology for $\mathrm{Cr}(\mathrm{VI})$ reduction, and their principle is presented in Fig. 1. In the anode, electrons released from organic compounds are transferred to the cathode using bacteria as "catalysts". In the cathode, which can also utilise bacterial catalysts (biocathode), electrons are received by $\mathrm{Cr}(\mathrm{VI})$ as the final step of the process. When a resistor is externally applied to the system, electrical power is generated by the electron movement from the anode to the cathode, which improves the sustainability of the remediation process. To close the electrical circuit and to run Eq. 1, protons are also delivered to the cathode through a proton or a cation exchange membrane.

Research on $\mathrm{Cr}(\mathrm{VI})$-reducing cathodes is summarised in Table 1 for abiotic cathodes and in Table 2 for biocathodes. Until now, MFC studies were conducted with either abiotic cathodes mainly operating at acidic $\mathrm{pH}$ (Table 1) or with biocathodes mainly operating at near neutral $\mathrm{pH}$ (Table 2). In addition, most work on microbial $\mathrm{Cr}(\mathrm{VI})$ remediation has been conducted near the physiological $\mathrm{pH}$ 7; however, chromium ore processing residue can have typical $\mathrm{pH}$ values as high as 8 and 9 (Stewart et al. 2007), and neutral $\mathrm{pH}$ will rather be the exception than the rule in this instance.

When at acidic $\mathrm{pH}, \mathrm{Cr}(\mathrm{VI})$ reduction occurs rather fast due to the abundance of protons (Eqs. 1,2) and the final product is mainly soluble $\mathrm{Cr}^{3+}$ (Fig. 2). However, protons are not abundant at neutral or alkaline $\mathrm{pH}$, and therefore, the process is very much slowed down. In addition, the charge of the final product of the reduction process (Cr(III)) will vary with varying $\mathrm{pH}$ (Fig. 2), and positively charged $\mathrm{Cr}(\mathrm{III})$ compounds will be deposited on the negatively charged MFC cathode (Clark and McCreery 2002; Hurley and McCreery 2003). Because Cr(VI) remediation in MFCs relies on electrochemical $\mathrm{Cr}(\mathrm{VI})$ reduction, this electrodeposition will result in a self-inhibitory behaviour of the cathode, and finally in a poor ratio of $\mathrm{Cr}(\mathrm{VI})$ reduced per electrode surface area.

A solution to this problem would be to maximise the ratio of electrode surface area used per mass of $\mathrm{Cr}(\mathrm{VI})$ available for reduction; however, this option would be impractical for real scale applications where the mass of $\mathrm{Cr}(\mathrm{VI})$ that needs to be reduced is high. In a previous study (Xafenias et al. 2013), we demonstrated that lactate can act as a $\mathrm{Cr}(\mathrm{III})$-chelating agent, enhancing the performance of neutral $\mathrm{pH}$ cathodes. However, neutral $\mathrm{pH}$ will rarely be the case of $\mathrm{Cr}(\mathrm{VI})$-contaminated environments, and therefore, the effectiveness of this approach has to be tested at different $\mathrm{pH}$ ranges.

Another important aspect of operating $\mathrm{Cr}(\mathrm{VI})$-reducing MFCs is the toxicity of $\mathrm{Cr}(\mathrm{VI})$ that might be present in the anode. $\mathrm{Cr}(\mathrm{VI})$ could be transferred to the anode by reactor failure, or by selecting an anion exchange membrane that would allow the negatively charged $\mathrm{Cr}(\mathrm{VI})$ oxides to be transferred from the cathode to the anode (Pandit et al. 2011). Therefore, evaluating $\mathrm{Cr}(\mathrm{VI})$ toxicity in MFC anodes is essential, and no other work has been published on this issue.

The aim of this study was to study issues related to $\mathrm{Cr}(\mathrm{VI})$ wastewater remediation in MFCs, with a focus on the challenging alkaline $\mathrm{pH}$ and on $\mathrm{Cr}(\mathrm{VI})$ toxicity in the anodes. For this reason, we selected three different $\mathrm{pH}$ values $(6,8$, and 9) and we studied how changing the cathodic $\mathrm{pH}$ from slightly acidic to alkaline affects the MFC performance. We also used a biocathode to test the effect of the biocatalyst present in an alkaline cathode, in order to merge traditional biological remediation with MFC technology. Finally, we tested the effect of $\mathrm{Cr}(\mathrm{VI})$ presence in MFC anodes, and we discuss the reasons behind this effect and why $\mathrm{Cr}(\mathrm{VI})$ presence in the anodes should be avoided. The work was conducted in 2012, in the Environmental Research laboratories of the Faculty of 


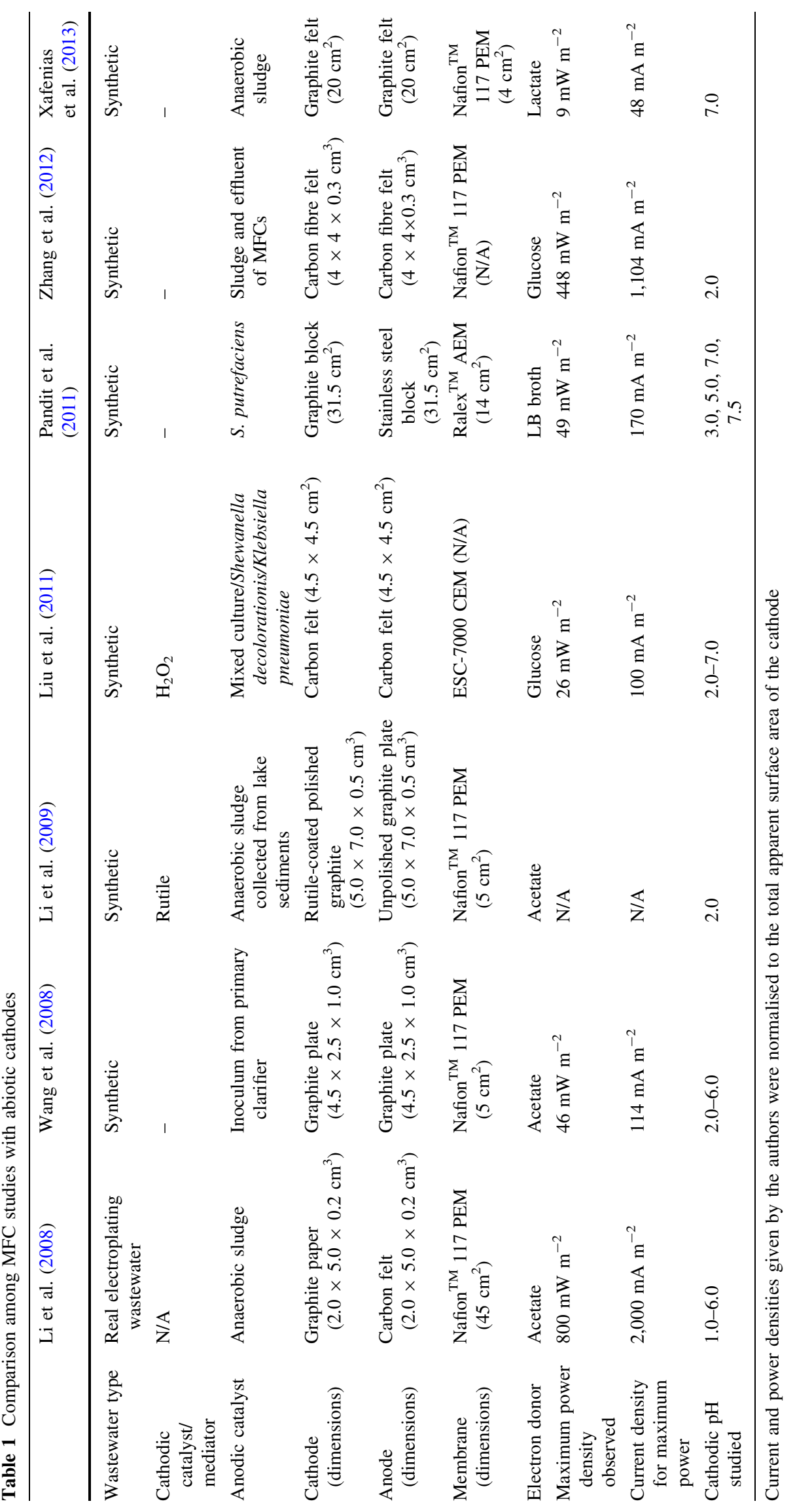




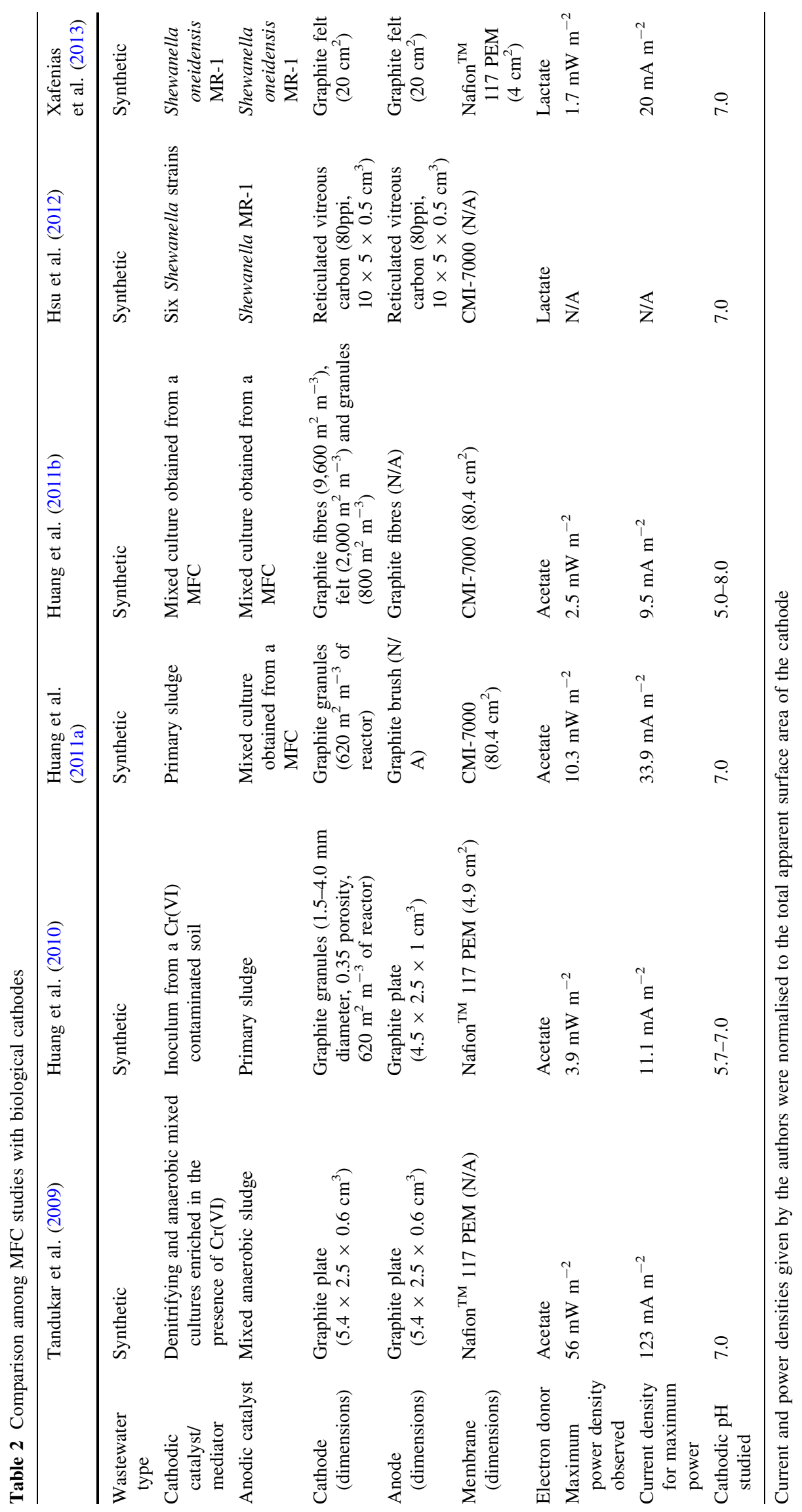




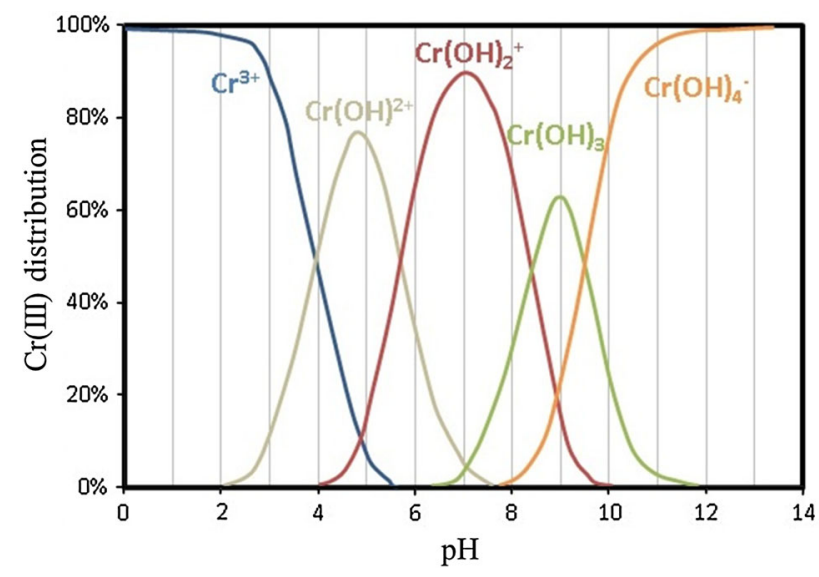

Fig. $2 \mathrm{Cr}$ (III) speciation changes with $\mathrm{pH}$ [adapted from Sun et al. (2010), with permissions]. At $\mathrm{pH} \mathrm{6}$, only positively charged $\mathrm{Cr}$ (III) species $\left(\mathrm{Cr}(\mathrm{OH})^{2+}, \mathrm{Cr}(\mathrm{OH})_{2}^{+}\right)$are present in solution. At $\mathrm{pH} 8$, mainly positive $\left(\mathrm{Cr}(\mathrm{OH})_{2}^{+}\right)$species remain in solution, while $\mathrm{Cr}(\mathrm{OH})_{3}$ species are removed from the solution by precipitation. At $\mathrm{pH} 9$, both positively $\left(\mathrm{Cr}(\mathrm{OH})_{2}^{+}\right)$and negatively $\left(\mathrm{Cr}(\mathrm{OH})_{4}^{-}\right)$charged dissolved species are present, along with the neutral $\mathrm{Cr}(\mathrm{OH})_{3}$ species that precipitate

Engineering and the Environment, University of Southampton, UK.

\section{Materials and methods}

\section{Reactor setup}

Common dual-chamber electrochemical reactors were used in this study, with $200 \mathrm{ml}$ working volume in each chamber. A Nafion 117 proton exchange membrane that was fixed between the two chambers had a surface area of $4 \mathrm{~cm}^{2}$ and was pretreated as described by Kim et al. (2007). Each chamber was hosting one graphite felt electrode with a $20-\mathrm{cm}^{2}$ total apparent surface area. One millimetre copper wire was used as the external circuit cable and was connected with the felt through a 3-mm $\varnothing$ graphite rod using conductive silver epoxy. Electrodes were cleaned prior to use as described by Chaudhuri and Lovley (2003). To avoid interference with Cr(III) deposits, new electrodes were used for each experiment. Ag/ $\mathrm{AgCl}$ reference electrodes were used in the MFCs to monitor the potential. All reactors were covered with aluminium foil to exclude light, and experiments were conducted at room temperature $\left(24 \pm 2{ }^{\circ} \mathrm{C}\right) . \mathrm{N}_{2}$ was flushed at all times in both the anode and the cathode of the $\mathrm{Cr}(\mathrm{VI})$-reducing MFCs except if otherwise indicated. External resistor $\left(R_{\text {ext }}\right)$ was 1,000 $\Omega$ at all times except if otherwise indicated.
Chemicals

In all cases, anodes were filled up to $200 \mathrm{ml}$ with a $\mathrm{pH} 7$ phosphate buffer minimal medium containing (mM): $\mathrm{NaCl}$ (70), $\mathrm{KH}_{2} \mathrm{PO}_{4}$ (21), $\mathrm{K}_{2} \mathrm{HPO}_{4}$ (29), $\mathrm{MgCl}_{2}$ (1), $\mathrm{NH}_{4} \mathrm{Cl}$ (28), and $\mathrm{CaCl}_{2}$ (0.7). The medium also contained $0.1 \% \mathrm{v} / \mathrm{v}$ of a trace elements mixture (Rabaey et al. 2005). A 1.2-M Naacetate (S2889, Sigma Aldrich) stock solution was prepared in anodic medium and was supplied in the mediatorless MFC anodes operating with anaerobic sludge to increase acetate concentration to around $40 \mathrm{mM}$ before each experiment. When Shewanella oneidensis MR-1 (MR-1) was used, anolyte contained Na-DL-Lactate (F1506, Sigma Aldrich) at the concentrations mentioned.

When studying $\mathrm{Cr}(\mathrm{VI})$ reduction at different $\mathrm{pH}$ values, the catholyte was a $50-\mathrm{mM}$ phosphate buffer saline (PBS) containing (mM): $\mathrm{KH}_{2} \mathrm{PO}_{4}(44), \mathrm{K}_{2} \mathrm{HPO}_{4}$ (6) at $\mathrm{pH}$ 6, $\mathrm{KH}_{2} \mathrm{PO}_{4}(3), \mathrm{K}_{2} \mathrm{HPO}_{4}(47)$ at $\mathrm{pH}$, and $\mathrm{KH}_{2} \mathrm{PO}_{4}(0)$, $\mathrm{K}_{2} \mathrm{HPO}_{4}(50)$ at $\mathrm{pH}$ 9. When studying $\mathrm{Cr}(\mathrm{VI})$ reduction in a pH 8 biocathode, the catholyte was the same as the anodic medium described above, amended to contain (mM): $\mathrm{KH}_{2} \mathrm{PO}_{4}$ (3) and $\mathrm{K}_{2} \mathrm{HPO}_{4}$ (47). $\mathrm{pH}$ in the reactors was corrected using $5 \mathrm{M} \mathrm{HCl}$ or $5 \mathrm{M} \mathrm{NaOH}$ solutions. Ovendried potassium dichromate $\left(\mathrm{K}_{2} \mathrm{Cr}_{2} \mathrm{O}_{7}\right)$ salt was diluted in ultra-pure water to make a $4-\mathrm{g} \mathrm{Cr}(\mathrm{VI}) 1^{-1}$ stock solution, which was then spiked in the cathodes to give an initial concentration of $10 \mathrm{mg} \mathrm{l}^{-1}$, except if otherwise indicated. Catholyte also contained $200 \mathrm{mM}$ of Na-DL-Lactate as a chelating agent in all cases.

Start-up and operation

Anaerobic sludge was used as the bacterial catalyst in the anodes of MFCs used to study $\mathrm{Cr}(\mathrm{VI})$ reduction at different $\mathrm{pH}$ values. The initial seed was obtained from the wastewater treatment plant of Millbrook, Southampton, UK, and was used to inoculate $(5 \mathrm{ml})$ an MFC anode fed with acetate in a fed-batch mode for more than 3 months. About $15 \mathrm{ml}$ of this MFC effluent was then used to inoculate the anodes in each of the three MFCs used, which were initially running with continuous air supply in the cathode and an external resistor. After biofilm formation in the anodes, the catholyte was replaced with anaerobic catholyte-containing $\mathrm{Cr}(\mathrm{VI})$ as the final electron acceptor, at the $\mathrm{pH}$ values mentioned.

\section{Shewanella oneidensis}

MR-1 was used in both the anode and cathode of the biocathode MFC and in the anode of the MFC used to test $\mathrm{Cr}(\mathrm{VI})$ toxicity in the anode. MR-1 (NCIMB 14063) was initially grown aerobically on tryptone soya agar $(\mathrm{pH} 7.3$, 
$30{ }^{\circ} \mathrm{C}$ ) and then transferred into $200 \mathrm{ml}$ of a Luria-Bertani 50-mM phosphate buffer medium (pH 7.0). After incubation in an orbital-shaking incubator at $30{ }^{\circ} \mathrm{C}$, cells were centrifuged $\left(5,000 \times g, 4{ }^{\circ} \mathrm{C}, 20 \mathrm{~min}\right)$, and then, the pellet was rinsed twice using $100 \mathrm{mM} \mathrm{NaCl}-50 \mathrm{mM}$ phosphate buffer saline (PBS) solution $(\mathrm{pH}$ 7.0). Cells were then harvested and resuspended in $200 \mathrm{ml}$ of a minimal medium to achieve an $\mathrm{OD}_{600}$ of 0.7 at the beginning of the experiments. When MR-1 was used in the biocathode MFC, MR1 was initially inoculated in one chamber of the MFC and was let to produce anodic current for 3 days with lactate as the electron donor and an external resistor. Air was constantly provided in the anodes at $160 \mathrm{ml} \mathrm{min}^{-1}$ using an air pump, in order to form a thick MR-1 biofilm and to sustain bacterial growth. After 3 days, MR-1 was also inoculated in the second chamber of the MFC; $\mathrm{N}_{2}$ was constantly sparged to remove all oxygen present in the ex-anode side; and current was let drop to background levels. $\mathrm{Cr}$ (VI) was then added in the ex-anode side, which then started operating as the cathode. When studying the effect of $\mathrm{Cr}$ (VI) presence in the anodes, two MFCs were inoculated with the $\mathrm{Cr}(\mathrm{VI})$ tolerant strain MR-1 and were let to produce current for around $20 \mathrm{~h}$, with $\mathrm{Cr}(\mathrm{VI})$ as the electron acceptor in the cathode $\left([\mathrm{Cr}(\mathrm{VI})]_{0}=500 \mathrm{mg} \mathrm{l}^{-1}\right.$, cathode $\left.\mathrm{pH} 2\right)$. Each MFC then had $\mathrm{Cr}(\mathrm{VI})$ added under anaerobic conditions (continuous $\mathrm{N}_{2}$ sparging), to give a concentration of around $10 \mathrm{mg} \mathrm{l}^{-1}$ in the anode. Then, current was allowed to stabilise for several hours and further $\mathrm{Cr}(\mathrm{VI})$ additions followed similarly. Appropriate sterilisation techniques were applied at all times to avoid contamination of the pure culture.

\section{Analytical methods}

Samples were centrifuged at $20,800 \times g$ for $3 \mathrm{~min}$, prior to $\mathrm{Cr}(\mathrm{VI})$ and acids analyses. The presence of dissolved $\mathrm{Cr}(\mathrm{VI})$ was evaluated as described in the Standard Method 3500-Cr B (APHA 2005). Acetate and lactate were measured using Ion Chromatography (882 Compact IC Plus, Metrohm) with an ion-exclusion column (Metrosep Organic Acids, 250/7.8 mm, Metrohm), a 0.5- $\mathrm{mM} \mathrm{H}_{2} \mathrm{SO}_{4}$ solution as eluent, and flow rate set at $0.6 \mathrm{ml} \mathrm{min}^{-1}$.

\section{Calculations}

Voltage drops across an external resistor were recorded every 2 min using a datalogger (DT 505, DataTaker). Current $I$ (A) was calculated according to the Ohm's law $I=E_{\text {cell }} / R_{\text {ext }}$, where $E_{\text {cell }}(\mathrm{V})$ is the voltage drop across the external resistor $R_{\text {ext }}(\Omega)$. Power $P$ was calculated as $P=E_{\text {cell }}^{2} / R_{\text {ext }}$. All current and power densities reported herein were calculated by dividing the current and power by the total apparent surface area of the cathode $\left(20 \mathrm{~cm}^{2}\right)$.
Charge transferred from the cathode electrode to the bulk solution was calculated as $C_{1}=\Sigma I \Delta t$, where $\mathrm{t}$ is the time interval between the two measurements $(120 \mathrm{~s})$. The total amount of charge transferred to $\mathrm{Cr}(\mathrm{VI})$, assuming a complete $\mathrm{Cr}(\mathrm{VI})$ to $\mathrm{Cr}(\mathrm{III})$ reduction, was calculated as $C_{2}=n F v \Delta[\mathrm{Cr}(\mathrm{VI})] / M$, where $n$ is the number of $3 \mathrm{~mol}$ of electrons needed to reduce $1 \mathrm{~mol}$ of $\mathrm{Cr}(\mathrm{VI})$ to $\mathrm{Cr}(\mathrm{III}), F$ is the Faraday constant $(96,485.3$ Coulombs/mol of electrons), $v$ is the catholyte volume $(200 \mathrm{ml}), \Delta[\mathrm{Cr}(\mathrm{VI})]$ is the reduction of $\mathrm{Cr}(\mathrm{VI})$ at a given time interval $\left(\mathrm{g} \mathrm{l}^{-1}\right)$ and $M$ is the atomic weight of $\mathrm{Cr}\left(52 \mathrm{~g} \mathrm{~mol}^{-1}\right)$. After calculating $C_{1}$ and $C_{2}$, Coulombic efficiency (CE, \%) of the cathode was calculated as $\mathrm{CE}=C_{1} / C_{2} \times 100 \%$.

\section{Polarisation curves}

Polarisation curves were obtained before the $\mathrm{Cr}(\mathrm{VI})$ reduction tests, and after a stable open circuit, voltage was recorded under continuous $\mathrm{N}_{2}$ flushing. $R_{\text {ext. }}$ from 100,000 to $3 \Omega$ were then applied, and graphs were made after voltage was not substantially changing for each of the $R_{\text {ext. }}$ applied.

\section{Results and discussion}

$\mathrm{Cr}(\mathrm{VI})$ reduction at different $\mathrm{pH}$ values

In a preliminary experiment with a poised cathode $(-500 \mathrm{mV}$ vs. $\mathrm{Ag} / \mathrm{AgCl})$ at $\mathrm{pH} 8$ and in the absence of lactate, electroreduction was minimal (less than $0.5 \mathrm{mg}$ $\mathrm{Cr}(\mathrm{VI}) \mathrm{l}^{-1}$ ), and current production reached background levels within $17 \mathrm{~h}$ of operation (data not shown). Therefore, in order to study $\mathrm{Cr}(\mathrm{VI})$ reduction at different $\mathrm{pH}$ values, all catholytes contained $200 \mathrm{mM}$ lactate which is a known metal chelator that can form chelates with $\mathrm{Cr}$ (III) (Hamada et al. 2005; Puzon et al. 2005) and thus enhance the $\mathrm{Cr}(\mathrm{VI})$ electroreduction process by limiting $\mathrm{Cr}(\mathrm{III})$ electrodeposition on the cathode (Xafenias et al. 2013). The reason we used lactate among other metal chelators is that it occurs naturally in the environment, it exhibits low environmental toxicity (Bowmer et al. 1998), it is easily biodegradable by bacteria of environmental interest like Shewanella (Pinchuk et al. 2011) and can be used as an electron donor for $\mathrm{Cr}(\mathrm{VI})$ bioremediation (Brodie et al. 2011; Alam et al. 2006).

Polarisation graphs (Fig. 3a) produced at the beginning of the experiments showed that power production at $\mathrm{pH} 8$ was maximum at the current density of $104 \mathrm{~mA} \mathrm{~m}^{-2}$, when $21 \mathrm{~mW} \mathrm{~m}^{-2}$ were produced. While power was increased at slightly acidic $\mathrm{pH} 6\left(25 \mathrm{~mW} \mathrm{~m}^{-2}\right.$ at $\left.112 \mathrm{~mA} \mathrm{~m}^{-2}\right)$ as can be explained by the Nernst equation, power densities at $\mathrm{pH}$ 9 were considerably lower compared with the $\mathrm{pH} 8$ 

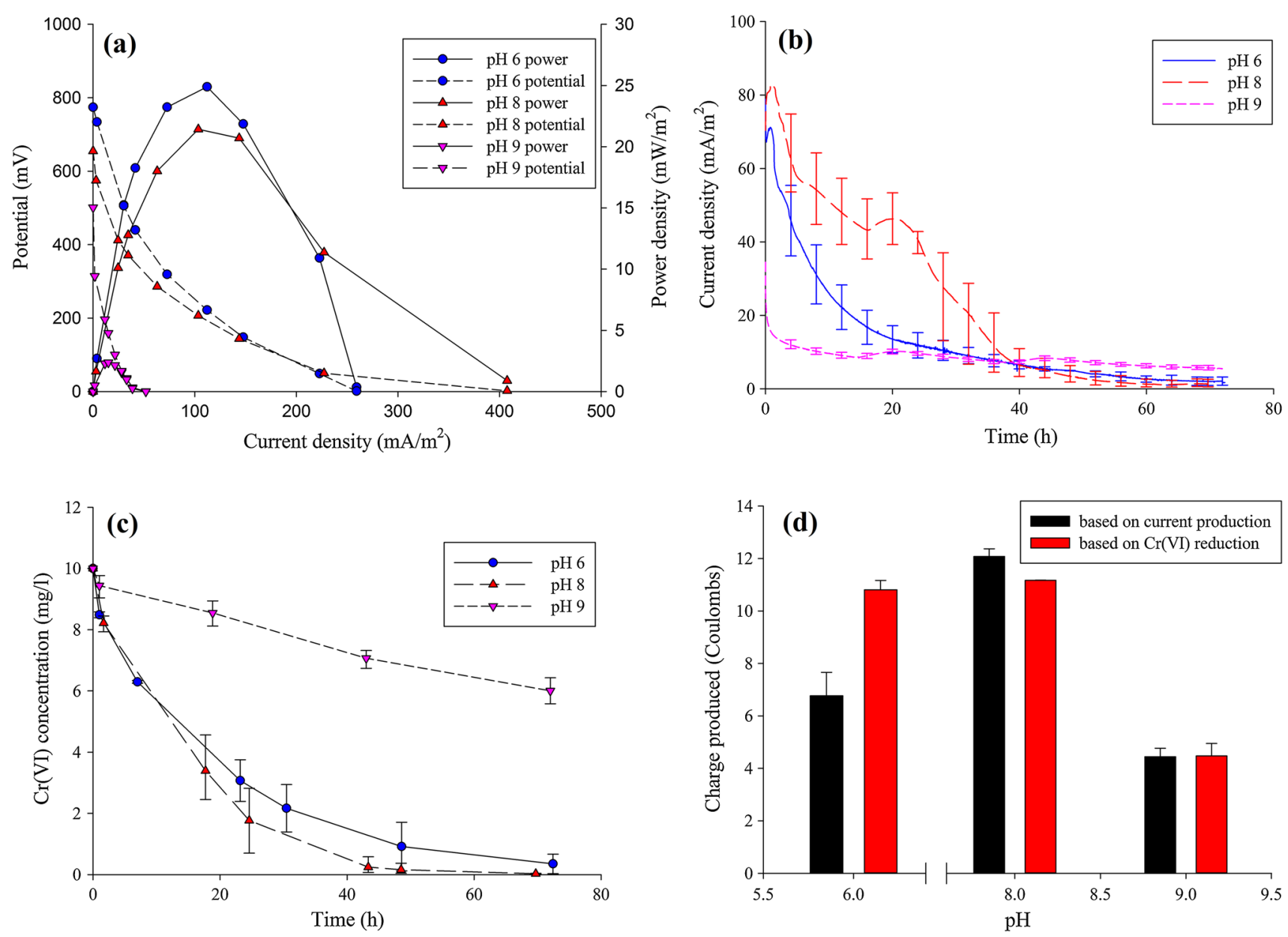

Fig. 3 MFC experiments with anaerobic sludge in the anode and abiotic cathodes with $\mathrm{Cr}(\mathrm{VI})$ at three different $\mathrm{pH}$ values $(200 \mathrm{mM}$ lactate in all cathodes): a polarisation graphs conducted at start; b current evolution through time $\left(R_{\text {ext. }}=1,000 \Omega\right)$; $\mathrm{Cr}(\mathrm{VI})$ remaining in the solution; d charge produced by the end of the $72-\mathrm{h}$

cathodes $\left(2 \mathrm{~mW} \mathrm{~m}^{-2}\right.$ at $\left.15 \mathrm{~mA} \mathrm{~m}^{-2}\right)$. Figure $3 \mathrm{~b}$ demonstrates the higher current production by the MFCs operating with the cathode at $\mathrm{pH} 8$, resulting in faster $\mathrm{Cr}(\mathrm{VI})$ reduction compared with other $\mathrm{pH}$ values (Fig. $3 \mathrm{c}$ ). $\mathrm{pH} 8$ cathodes exhibited more efficient $\mathrm{Cr}(\mathrm{VI})$ reduction even compared with $\mathrm{pH} 6$ cathodes, regardless of the fact that both systems had an initial current production of around $70 \mathrm{~mA} \mathrm{~m}{ }^{-2}$. As a result, $\mathrm{Cr}(\mathrm{VI})$ levels in $\mathrm{pH} 8 \mathrm{MFCs}$ fell to less than $0.3 \pm 0.3 \mathrm{mg} \mathrm{l}^{-1}$ within the first $43 \mathrm{~h}$ of operation, while at $\mathrm{pH} 6$, the same levels of $\mathrm{Cr}(\mathrm{VI})$ remaining in solution were only achieved at the end of the 72-h operation period. At $\mathrm{pH} 9, \mathrm{Cr}(\mathrm{VI})$ was continuously reduced; however, reduction rates were slower, and there were still $6 \pm 0.4 \mathrm{mg} \mathrm{l}^{-1}$ available at the end of the operation period.

Anodic potential under closed circuit conditions did not alter much during operation $(\mathrm{pH}$ 6: $-531 \pm 49 \mathrm{mV}, \mathrm{pH} 8$ : $-542 \pm 21 \mathrm{mV}, \mathrm{pH} 9:-558 \pm 4 \mathrm{mV})$. Anodic $\mathrm{pH}$ did not

operation period (charge calculated based on both current production and $\mathrm{Cr}(\mathrm{VI})$ reduction). In $\mathbf{b}-\mathbf{d}$, values reported are average of triplicate experiments for $\mathrm{pH} 8$ and 9 and duplicate experiments for $\mathrm{pH}$ 6. Error bars represent the min and max of the measurements from the reactors running in parallel

alter much either and remained around 7.9 throughout operation. Therefore, it should mainly be cathode-related factors that have contributed to the higher current production observed at $\mathrm{pH}$ 8. One might assume an increased stability of the $\mathrm{Cr}(\mathrm{III})$-lactate complex with increasing $\mathrm{pH}$, as a result of stronger deprotonation of the lactic ion. Increased stability could limit the electrodeposition of $\mathrm{Cr}$ (III) compounds on the cathode electrode and therefore the deactivation of the cathode. However, with a low $\mathrm{p} K_{\mathrm{a}}$ value for the carboxyl (3.86) and a high $\mathrm{p} K_{\mathrm{a}}$ value for the hydroxyl (15.1) group (Silva et al. 2009), the protonation state of the lactic ion would not alter much within the $\mathrm{pH}$ range studied.

Another more likely explanation would involve the speciation of $\mathrm{Cr}(\mathrm{III})-$ lactate complexes with varying $\mathrm{pH}$. In an aquatic environment, four $\mathrm{Cr}(\mathrm{III})$ species are dominant within the pH range 6-9 (Sun et al. 2010): $\mathrm{Cr}(\mathrm{OH})^{2+}$ and $\mathrm{Cr}(\mathrm{OH})_{2}^{+}$at $\mathrm{pH} 6 ; \mathrm{Cr}(\mathrm{OH})_{2}^{+}$at $\mathrm{pH} 7 ; \mathrm{Cr}(\mathrm{OH})_{2}^{+}$and $\mathrm{Cr}(\mathrm{OH})_{3}$ 
Table 3 Comparison among MFC studies conducted between slightly acidic (pH 6) to alkaline (pH 9) conditions

\begin{tabular}{|c|c|c|c|c|c|c|}
\hline $\mathrm{pH}$ & $\begin{array}{l}\text { Maximum power } \\
\text { density observed } \\
\left(\mathrm{mW} \mathrm{m}{ }^{-2}\right)\end{array}$ & $\begin{array}{l}\text { Current density for } \\
\text { maximum power } \\
\left.(\mathrm{mA} \mathrm{m})^{-2}\right)\end{array}$ & $\begin{array}{l}{[\mathrm{Cr}(\mathrm{VI})]} \\
\left(\mathrm{mg} \mathrm{l}^{-1}\right)\end{array}$ & $\begin{array}{l}\text { Biocatalyst in } \\
\text { the cathode }\end{array}$ & $\begin{array}{l}\text { Electrode surface area } \\
\text { per cathodic working } \\
\text { volume }\left(\mathrm{m}^{2} \mathrm{~m}^{-3}\right)\end{array}$ & Reference \\
\hline 6 & 23.0 & - & 100 & No & 15 & Wang et al. (2008) \\
\hline 6 & 24.9 & 112.0 & 10 & No & 10 & This study \\
\hline 6 & 29.6 & - & 50 & No & 10 & Li et al. (2008) \\
\hline 7 & 0.2 & 2.3 & 39 & No & $620(340-900)$ & Huang et al. (2010) \\
\hline 7 & 0.2 & 2.4 & 20 & No & 9,600 & Huang et al. (2011b) \\
\hline 7 & 2.5 & 9.5 & 20 & Yes & 800 & Huang et al. (2011b) \\
\hline 7 & 3.9 & 11.1 & 39 & Yes & $620(340-900)$ & Huang et al. (2010) \\
\hline 7 & 7.9 & 46.6 & 22 & Yes & 16 & Tandukar et al. (2009) \\
\hline 7 & 11.0 & 54.8 & 31 & & & \\
\hline 7 & 24.7 & 83.2 & 40 & & & \\
\hline 7 & 55.5 & 123.4 & 63 & & & \\
\hline 7 & 8.8 & 47.6 & 10 & No & 10 & Xafenias et al. (2013) \\
\hline 7 & 10.3 & 33.9 & 20 & Yes & $620(340-900)$ & Huang et al. (2011a) \\
\hline 8 & 0.7 & 2.1 & 20 & Yes & 9,600 & Huang et al. (2011b) \\
\hline 8 & 21.4 & 103.5 & 10 & No & 10 & This study \\
\hline 9 & 2.4 & 15.0 & 10 & No & 10 & This study \\
\hline
\end{tabular}

at $\mathrm{pH} 8 ; \mathrm{Cr}(\mathrm{OH})_{2}^{+}, \mathrm{Cr}(\mathrm{OH})_{3}$ and $\mathrm{Cr}(\mathrm{OH})_{4}^{-}$at $\mathrm{pH}$ 9. Considering a 1:1 lactate-Cr(III) chelation (Hamada et al. 2005), complexes at lower $\mathrm{pH}$ might have retained a positive charge, which attracted them on the negatively charged electrode surface. $\mathrm{Cr}$ (III) can be deposited on the electrode even after reduction at $\mathrm{pH}$ as low as 2 (Zhang et al. 2012); however, the higher $\mathrm{H}^{+}$availability at lower $\mathrm{pH}$ is probably counteracting this inhibition effect (Eq. 1) by increasing the cathode's reduction potential (Eq. 2).

Another reason for the rather slower electroreduction observed at $\mathrm{pH} 6$ was that at lower $\mathrm{pH}$, partial $\mathrm{Cr}(\mathrm{VI})$ reduction by nonelectrochemical pathways was observed. While Coulombic efficiency was close to $100 \%$ at $\mathrm{pH} 8$ and 9, at pH 6, it dropped to only $63 \%$ (Fig. 3d), indicating that another $\mathrm{Cr}(\mathrm{VI})$ removal pathway was present at lower $\mathrm{pH}$. With $\mathrm{Cr}(\mathrm{VI})$ at the $\mathrm{pH}$ range studied being mainly in the negative chromate ion $\left(\mathrm{CrO}_{4}{ }^{2-}\right)$ form, $\mathrm{Cr}(\mathrm{VI})$ cannot be electrostatically removed by the also negatively charged cathode (Farmer et al. 1997). A more possible mechanism which explains this decrease in Coulombic efficiency would be that of chemical $\mathrm{Cr}(\mathrm{VI})$ reduction by lactic acid (Deng and Stone 1996).

Until now, studies on $\mathrm{Cr}(\mathrm{VI})$ reduction at neutralslightly alkaline $\mathrm{pH}$ have mainly focused on the use of $\mathrm{Cr}$ (VI)-reducing bacterial catalysts in the cathode. Table 3 compares the maximum power densities recorded in the literature, with the ones observed in this study where lactate instead of a bacterial catalyst was used to enhance the process. At $\mathrm{pH} \mathrm{6,} \mathrm{the} \mathrm{power} \mathrm{density} \mathrm{produced} \mathrm{in} \mathrm{this} \mathrm{study}$ was comparable with previous studies that were performed in the absence of a metal chelator (Wang et al. 2008; Li et al. 2008). However, we only used $1 / 5$ to $1 / 10$ the concentration used elsewhere, and this should have reduced the redox potential of the $\mathrm{Cr}(\mathrm{VI}) / \mathrm{Cr}(\mathrm{III})$ couple, as predicted by the Nernst equation (Eq. 2). At pH 8 and 9, maximum power density produced by $10 \mathrm{mg} \mathrm{Cr}(\mathrm{VI}) / 1$ in the presence of lactate was 31 and 3 times, respectively, the power density produced in a biocathode MFC running with $20 \mathrm{mg}$ $\mathrm{Cr}$ (VI)/l at pH 8 (Huang et al. 2011b), indicating that the chelation process is crucial at these $\mathrm{pH}$ values.

Our discovery that chelation can enhance $\mathrm{Cr}(\mathrm{VI})$ electroremediation can be applied to elucidate the mechanisms via which bacterial catalysts enhance $\mathrm{Cr}(\mathrm{VI})$ reduction in MFC biocathodes. These mechanisms are still not clear; however, a possible reason for this enhancement could be because of $\mathrm{Cr}$ (III) chelation with organic acids excreted by bacteria (Vollbrecht et al. 1978) present in mixed bacterial biocathodes. In addition, it is of importance whether and how other chelate agents with environmental importance like citrate or EDTA can enhance $\mathrm{Cr}(\mathrm{VI})$ electroremediation. Finally, since organic molecules such as lactate can form insoluble complexes with $\mathrm{Cr}$ (III) at appropriate $\mathrm{pH}$ (Hamada et al. 2005; Puzon et al. 2005), the effluent of the $\mathrm{Cr}(\mathrm{VI})$-reducing cathode could be further environmentally improved by subsequent $\mathrm{pH}$ control, which would precipitate and remove total chromium. However, more research is needed on all of these aspects.

$\mathrm{Cr}(\mathrm{VI})$ reduction in a $\mathrm{pH} 8$ biocathode

To study whether biological remediation can be applied together with MFC technology at alkaline $\mathrm{pH}$, we tested a 

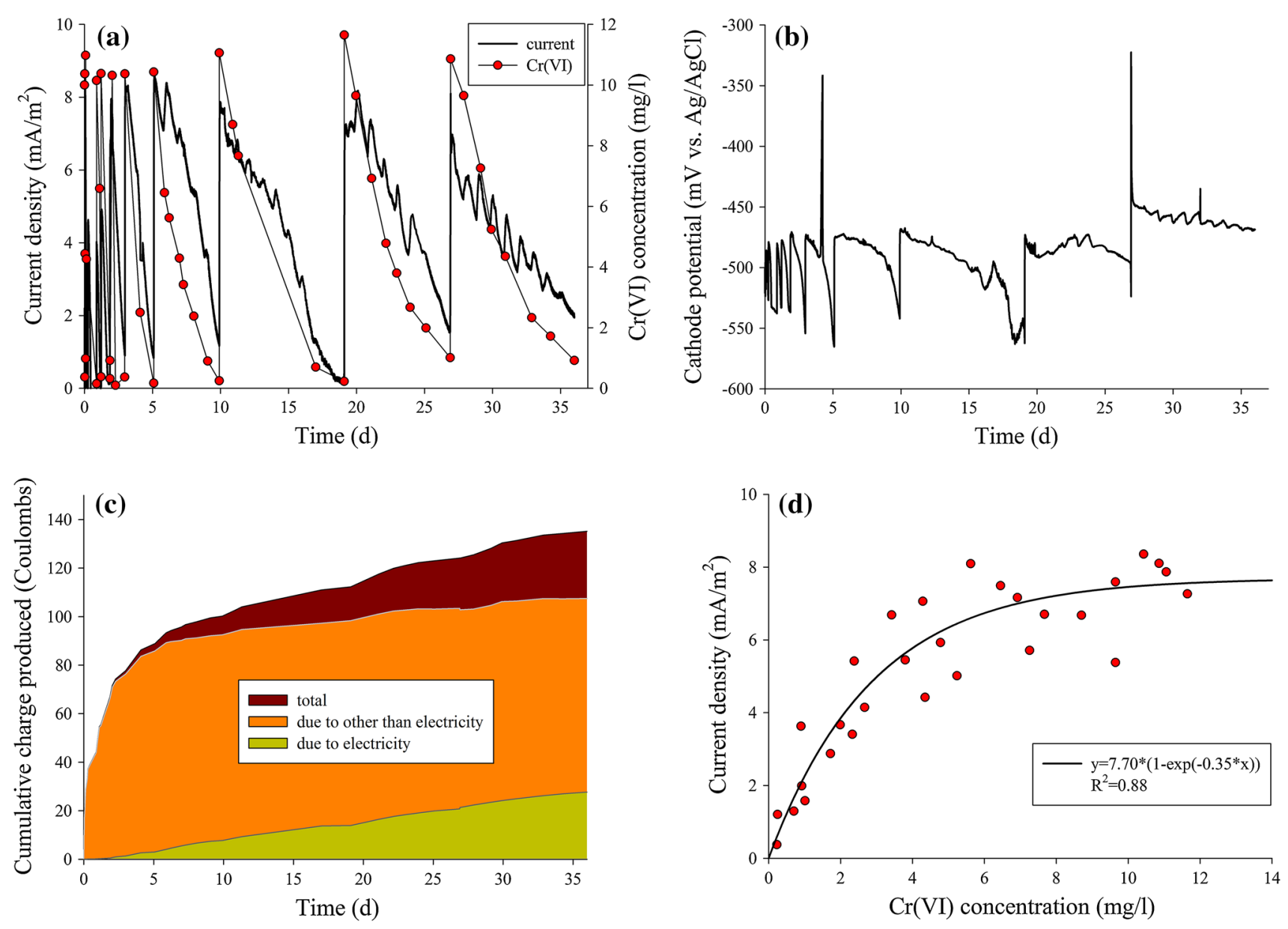

Fig. 4 The effect of $\mathrm{Cr}(\mathrm{VI})$ additions in an MFC cathode operating with $S$. oneidensis MR-1 as the biocatalyst in both anode and cathode $\left(R_{\text {ext. }}=1,000 \Omega\right)$ : a current production and $\mathrm{Cr}(\mathrm{VI})$ reduction through time; b cathode potential through time; c cumulative charge produced, calculated from $\mathrm{Cr}(\mathrm{VI})$ reduction (total), electricity

production (due to electricity), and the subtraction of the two (due to other than electricity); d current versus $\mathrm{Cr}(\mathrm{VI})$ concentration relationship calculated from the last four $\mathrm{Cr}(\mathrm{VI})$ additions to the biocathode

lactate-containing cathode in the presence of $\mathrm{MR}-1$, at $\mathrm{pH}$ 8. When $\mathrm{Cr}(\mathrm{VI})$ was added in the biocathode, the concentration was initially decreased rapidly (Fig. 4a) due to the $\mathrm{Cr}(\mathrm{VI})$-reducing metabolic pathways of MR-1 that did not involve current production. Cathode potential remained at low levels due to the presence of MR-1 (Fig. 4b); however, it was increased by around $50-70 \mathrm{mV}$ after each $\mathrm{Cr}(\mathrm{VI})$ addition. The charged produced, calculated both from the total $\mathrm{Cr}(\mathrm{VI})$ reduction and the electricity production, showed that the initial rapid $\mathrm{Cr}(\mathrm{VI})$ reduction was due to factors other than electricity (e.g. heterotrophic lactate oxidation). During the first 6 days of operation, 89.2 $\mathrm{C}$ of charge was produced in the biocathode due to nonelectricity factors, compared with only $4.1 \mathrm{C}$ produced due to electricity (Fig. 4c). However, during the next 30 days of operation, electricity production became the major and more stable $\mathrm{Cr}(\mathrm{VI})$ reduction pathway; 23.6 $\mathrm{C}$ was bioelectrochemically produced during this time, while only

18.3 C was produced due to other pathways. This finding is important, as it clearly demonstrates that bio-electroreduction can improve the traditional biological $\mathrm{Cr}(\mathrm{VI})$ remediation, even at alkaline $\mathrm{pH}$. Finally, the relationship between current produced and $\mathrm{Cr}(\mathrm{VI})$ concentration in the biocathode could be represented, with a high coefficient of determination $\left(r^{2}=0.88\right)$, by an exponential rise to a maximum equation (Fig. 4d); this indicates that the effect of $\mathrm{Cr}(\mathrm{VI})$ concentration on current production in the biocathode was crucial only up to a certain concentration; above that concentration (around $8 \mathrm{mg}-\mathrm{Cr}(\mathrm{VI}) / \mathrm{l}), \mathrm{Cr}(\mathrm{VI})$ would not produce considerably higher current density, nor $\mathrm{Cr}(\mathrm{VI})$ electroreduction would be considerably faster, given a certain electrode surface area. To overcome this limitation, and depending on the $\mathrm{Cr}(\mathrm{VI})$ concentration to be treated, a higher electrode surface area would be beneficial, as it would increase the absolute current value and therefore the $\mathrm{Cr}(\mathrm{VI})$ treatment rate. 

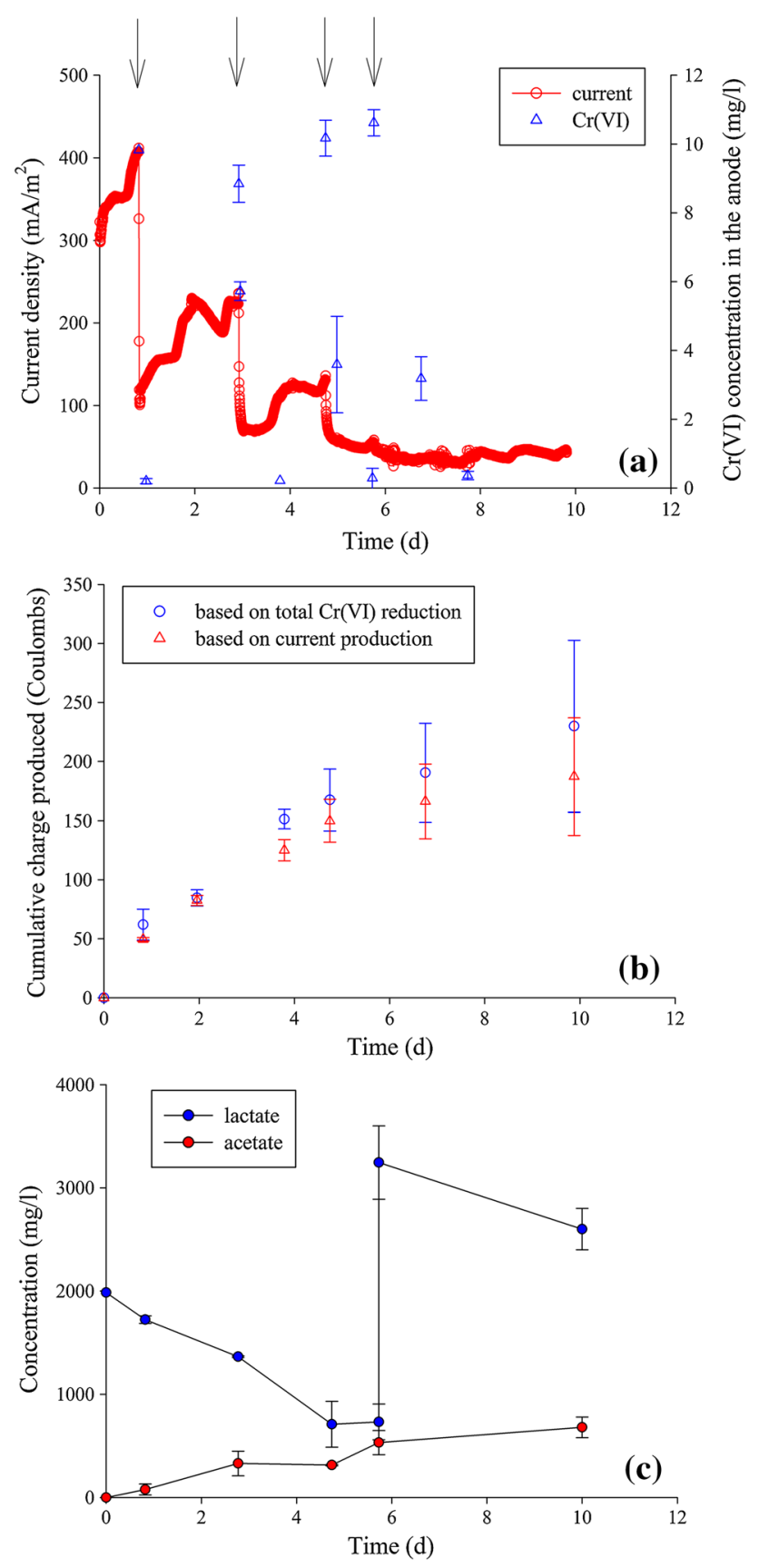

Fig. 5 The effect of $\mathrm{Cr}(\mathrm{VI})$ additions in an MFC anode operating with $S$. oneidensis MR-1 as the anodic biocatalyst $\left(R_{\text {ext. }}=1,000 \Omega\right)$ : a current production and $\mathrm{Cr}(\mathrm{VI})$ concentration in the anode (arrows indicate $\mathrm{Cr}(\mathrm{VI})$ spikes; average values from two reactors are reported, and error bars represent min and max); $\mathbf{b}$ on the cumulative charge produced by the MFC, calculated based on both current production and $\mathrm{Cr}(\mathrm{VI})$ reduction in the cathode; $\mathbf{c}$ lactate and acetate concentrations evolution in the anode

Anodic current inhibition by $\mathrm{Cr}(\mathrm{VI})$ present in the anode

In the previous paragraph, we demonstrated that sufficient $\mathrm{Cr}(\mathrm{VI})$ reduction can take place in MFC cathodes with lactate and MR-1 and that this reduction is the cumulative effect of both biological and electrochemical $\mathrm{Cr}(\mathrm{VI})$ reduction. Moving a step forward, it is important to demonstrate the effect that $\mathrm{Cr}(\mathrm{VI})$ can have on the activity of MR-1 when the later acts as the anodic biocatalyst.

As seen in Fig. 5a, current increased during the first $20 \mathrm{~h}$ of operation when MR-1 was utilising lactate to produce anodic current and $\mathrm{Cr}(\mathrm{VI})$ was absent from the anode. However, current density immediately dropped from 0.41 to $0.11 \mathrm{~A} \mathrm{~m}^{-2}$ after the first $\mathrm{Cr}(\mathrm{VI})$ addition $\left(9.8 \mathrm{mg} \mathrm{l}^{-1}\right)$, which corresponds to a $73 \%$ decrease. Current recovered slowly after complete $\mathrm{Cr}(\mathrm{VI})$ reduction but did not exceed $0.22 \mathrm{~A} \mathrm{~m}^{-2}$, even after 2 days of operation. After the second $\mathrm{Cr}(\mathrm{VI})$ addition $\left(8.8 \mathrm{mg} \mathrm{l}^{-1}\right)$, the current density dropped from 0.22 to $0.08 \mathrm{~A} \mathrm{~m}^{-2}$, corresponding to a further $67 \%$ drop. After 2 days of stabilisation, $\mathrm{Cr}(\mathrm{VI})\left(10.2 \mathrm{mg} \mathrm{l}^{-1}\right)$ was added for the third time, resulting in a further drop in current density by $67 \%$, from 0.11 to $0.04 \mathrm{~A} \mathrm{~m}^{-2}$. After this final drop, current density did not recover but stabilised at around $0.04 \mathrm{~A} \mathrm{~m}^{-2}$. $\mathrm{Cr}(\mathrm{VI})$ concentration in the anode dropped to low levels even after the fourth $\mathrm{Cr}(\mathrm{VI})$ addition (10.6 mg $~^{-1}$ ); however, current in this instance did not show any clear further response (increase or decrease). As a result of the current density dropping after each $\mathrm{Cr}(\mathrm{VI})$ addition, the rates of charge production calculated according to current production and cathodic $\mathrm{Cr}(\mathrm{VI})$ reduction also fell (Fig. 5b); this was despite the fact that sufficient amounts of the electron donor (lactate) were present in the anodes at all times (Fig. 5c).

The immediate drop of current as a response to $\mathrm{Cr}(\mathrm{VI})$ additions in the anode could be due to the alternative electron acceptor present in the anode, which is being reduced instead of the electrode. However, as demonstrated elsewhere, this was not the case when oxygen was supplied in the MR-1-inoculated anode (Rosenbaum et al. 2010; Xafenias et al. 2013). In addition, this would not explain the slow recovery (or the absence of any recovery) observed after $\mathrm{Cr}(\mathrm{VI})$ depletion. Passivation of the electroactive components responsible for anodic current production by $\mathrm{Cr}$ (III) precipitates on the bacterial cell surface could be a reason for the reduced electroactivity of MR-1 in the anode. However, recent findings suggesting that MR1 remained electroactive during $\mathrm{Cr}(\mathrm{VI})$ reduction and could utilise the electrode as electron donor during bioelectrochemical Cr(VI) reduction (Xafenias et al. 2013) and could indicate differences between the electron transfer pathways of anodic and cathodic current production. Uncomplexed $\mathrm{Cr}(\mathrm{III})$ formed during $\mathrm{Cr}(\mathrm{VI})$ reduction is known to have toxic effects on Shewanella, as it accumulates within the cytoplasm and probably binds with the DNA, affecting the cell's functionality (Bencheikh-Latmani et al. 2007). Therefore, the presence of $\mathrm{Cr}(\mathrm{VI})$ in the anodes of MFCs 
will have severe inhibitory effects on the process and must be avoided. This would be done by separating the anolyte from the catholyte using appropriately selective membranes (e.g. proton or cation exchange membranes and not anion exchange membranes), which would not allow the migration of the negatively charged $\mathrm{Cr}(\mathrm{VI})$ ions towards the anode.

\section{Conclusion}

Bio-electrochemical $\mathrm{Cr}(\mathrm{VI})$ reduction at alkaline cathodic $\mathrm{pH}$ is possible when chelating agents such as lactate are present. Current and power produced in the abiotic cathodes with lactate were at the same levels as those of microbially catalysed cathodes, and faster electrochemical reduction was achieved at $\mathrm{pH} 8$, compared with $\mathrm{pH} 6$ and 9. The presence of the cathode electrode in a biological $\mathrm{Cr}(\mathrm{VI})$-reducing system can have a positive cumulative effect, and $\mathrm{Cr}(\mathrm{VI})$ will be reduced by both the biocatalyst and the electrode. However, the presence of $\mathrm{Cr}(\mathrm{VI})$ in the anodes of bioelectrochemical systems must be prevented as it has been demonstrated to have an irreversible inhibitory effect on anodic current production.

Acknowledgments Funding in support of this work was provided by the Faculty of Engineering and the Environment, University of Southampton, UK.

\section{References}

Alam M, Hossain A, Yonge DR, Peyton BM, Petersen JN (2006) Bioreduction of hexavalent chromium in flow-through quartz sand columns. J Environ Eng 132(3):358-366

APHA (2005) Standard methods for the examination of water and wastewater. Standard Methods for the Examination of Water and Wastewater, 21st-Centennial edn. American Public Health Association (APHA), American Water Works Association (AWWA), Water Environment Federation (WEF), Washington DC

Bencheikh-Latmani R, Obraztsova A, Mackey MR, Ellisman MH, Tebo BM (2007) Toxicity of Cr(III) to Shewanella sp. strain MR-4 during $\mathrm{Cr}(\mathrm{VI})$ reduction. Environ Sci Technol 41(1):214-220. doi:10.1021/es0622655

Bowmer CT, Hooftman RN, Hanstveit AO, Venderbosch PWM, van der Hoeven N (1998) The ecotoxicity and the biodegradability of lactic acid, alkyl lactate esters and lactate salts. Chemosphere 37(7):1317-1333. doi:10.1016/s0045-6535(98)00116-7

Brandhuber P, Frey M, McGuire MJ, Chao P, Seidel C, Amy G, Yoon J, McNeill L, Banerjee K (2004) Low-level hexavalent chromium treatment options: bench-scale evaluation. American water works association Research Foundation

Brodie EL, Joyner DC, Faybishenko B, Conrad ME, Rios-Velazquez C, Malave J, Martinez R, Mork B, Willett A, Koenigsberg S, Herman DJ, Firestone MK, Hazen TC (2011) Microbial community response to addition of polylactate compounds to stimulate hexavalent chromium reduction in groundwater.
Chemosphere 85(4):660-665. doi:10.1016/j.chemosphere.2011. 07.021

Chaudhuri SK, Lovley DR (2003) Electricity generation by direct oxidation of glucose in mediatorless microbial fuel cells. Nat Biotechnol 21(10):1229-1232

Clark WJ, McCreery RL (2002) Inhibition of corrosion-related reduction processes via chromium monolayer formation. J Electrochem Soc 149(9):B379-B386

Deng B, Stone AT (1996) Surface-catalyzed chromium(VI) reduction: reactivity comparisons of different organic reductants and different oxide surfaces. Environ Sci Technol 30(8):2484-2494. doi:10.1021/es950780p

Farmer JC, Bahowick SM, Harrar JE, Fix DV, Martinelli RE, Vu AK, Carroll KL (1997) Electrosorption of chromium ions on carbon aerogel electrodes as a means of remediating ground water. Energy Fuels 11(2):337-347. doi:10.1021/ef9601374

Hamada YZ, Carlson B, Dangberg J (2005) Interaction of malate and lactate with chromium(III) and iron(III) in aqueous solutions. Synth React Inorg Met-Organ Nan-Met Chem 35(7):515-522. doi:10.1080/15533170500198887

Hsu L, Masuda SA, Nealson KH, Pirbazari M (2012) Evaluation of microbial fuel cell Shewanella biocathodes for treatment of chromate contamination. RSC Adv 2(13):5844-5855

Huang L, Chen J, Quan X, Yang F (2010) Enhancement of hexavalent chromium reduction and electricity production from a biocathode microbial fuel cell. Bioprocess Biosyst Eng 33(8):937-945

Huang L, Chai X, Chen G, Logan BE (2011a) Effect of set potential on hexavalent chromium reduction and electricity generation from biocathode microbial fuel cells. Environ Sci Technol 45(11):5025-5031. doi:10.1021/es103875d

Huang L, Chai X, Cheng S, Chen G (2011b) Evaluation of carbonbased materials in tubular biocathode microbial fuel cells in terms of hexavalent chromium reduction and electricity generation. Chem Eng J 166(2):652-661. doi:10.1016/j.cej.2010.11. 042

Hurley BL, McCreery RL (2003) Raman spectroscopy of monolayers formed from chromate corrosion inhibitor on copper surfaces. J Electrochem Soc 150(8):B367-B373

Kim JR, Cheng S, Oh S-E, Logan BE (2007) Power generation using different cation, anion, and ultrafiltration membranes in microbial fuel cells. Environ Sci Technol 41(3):1004-1009. doi:10. 1021/es062202m

Li ZJ, Zhang XW, Lei LC (2008) Electricity production during the treatment of real electroplating wastewater containing $\mathrm{Cr}^{6+}$ using microbial fuel cell. Process Biochem 43(12):1352-1358. doi:10.1016/j.procbio.2008.08.005

Li Y, Lu AH, Ding HR, Jin S, Yan YH, Wang CQ, Zen CP, Wang X (2009) $\mathrm{Cr}$ (VI) reduction at rutile-catalyzed cathode in microbial fuel cells. Electrochem Commun 11(7):1496-1499. doi:10.1016/ j.elecom.2009.05.039

Liu L, Yuan Y, Li F-b, Feng C-h (2011) In-situ Cr(VI) reduction with electrogenerated hydrogen peroxide driven by iron-reducing bacteria. Bioresour Technol 102(3):2468-2473. doi:10.1016/j. biortech.2010.11.013

Palmer CD, Puls RW (1994) Natural attenuation of hexavalent chromium in groundwater and soils. EPA Ground Water Issue. U.S. Environmental Protection Agency

Pandit S, Sengupta A, Kale S, Das D (2011) Performance of electron acceptors in catholyte of a two-chambered microbial fuel cell using anion exchange membrane. Bioresour Technol 102(3): 2736-2744. doi:10.1016/j.biortech.2010.11.038

Pinchuk GE, Geydebrekht OV, Hill EA, Reed JL, Konopka AE, Beliaev AS, Fredrickson JK (2011) Pyruvate and lactate metabolism by Shewanella oneidensis MR-1 under fermentative, oxygen-limited and fumarate-respiring conditions. Appl Environ Microbiol:AEM.05382-05311. doi:10.1128/aem.05382-11 
Puzon GJ, Roberts AG, Kramer DM, Xun L (2005) Formation of soluble organo-chromium(III) complexes after chromate reduction in the presence of cellular organics. Environ Sci Technol 39(8):2811-2817. doi:10.1021/es048967g

Rabaey K, Ossieur W, Verhaege M, Verstraete W (2005) Continuous microbial fuel cells convert carbohydrates to electricity. Water Sci Technol 52(1):515-523

Rosenbaum M, Cotta MA, Angenent LT (2010) Aerated Shewanella oneidensis in continuously fed bioelectrochemical systems for power and hydrogen production. Biotechnol Bioeng 105(5): 880-888

Silva A, Kong X, Hider R (2009) Determination of the pKa value of the hydroxyl group in the $\alpha$-hydroxycarboxylates citrate, malate and lactate by 13C NMR: implications for metal coordination in biological systems. Biometals 22(5):771-778. doi:10.1007/ s10534-009-9224-5

Stewart DI, Burke IT, Mortimer RJG (2007) Stimulation of microbially mediated chromate reduction in alkaline soil-water systems. Geomicrobiol J 24(7):655-669

Sun X-F, Ma Y, Liu X-W, Wang S-G, Gao B-Y, Li X-M (2010) Sorption and detoxification of chromium(VI) by aerobic granules functionalized with polyethylenimine. Water Res 44(8):2517-2524

Tandukar M, Huber SJ, Onodera T, Pavlostathis SG (2009) Biological chromium(VI) reduction in the cathode of a microbial fuel cell. Environ Sci Technol 43(21):8159-8165. doi:10.1021/es9014184
U.S.E.P.A. (2000) In situ treatment of soil and groundwater contaminated with chromium-technical resource guide. U.S. Environmental Protection Agency, Office of Research and Development, Washington DC

Vollbrecht D, Nawawy MA, Schlegel HG (1978) Excretion of metabolites by hydrogen bacteria I. Autotrophic and heterotrophic fermentations. Eur J Appl Microbiol Biotechnol 6(2): 145-155. doi:10.1007/bf00504426

Wang G, Huang LP, Zhang YF (2008) Cathodic reduction of hexavalent chromium $[\mathrm{Cr}(\mathrm{VI})]$ coupled with electricity generation in microbial fuel cells. Biotechnol Lett 30(11):1959-1966. doi:10.1007/s10529-008-9792-4

Xafenias N, Zhang Y, Banks C (2013) Enhanced performance of hexavalent chromium reducing cathodes in the presence of Shewanella oneidensis MR-1 and lactate. Environ Sci Technol 47(9):4512-4520. doi:10.1021/es304606u

Zhang B, Feng C, Ni J, Zhang J, Huang W (2012) Simultaneous reduction of vanadium (V) and chromium (VI) with enhanced energy recovery based on microbial fuel cell technology. J Power Sour. doi:10.1016/j.jpowsour.2012.01.013 